\title{
Life Stage-Specific Hydropeaking Flow Rules
}

\author{
Daniel S. Hayes ${ }^{1,2, *} \mathbb{D}$, Miguel Moreira ${ }^{3}$, Isabel Boavida ${ }^{3}\left(\mathbb{D}\right.$, Melanie Haslauer $^{1}{ }^{(0}$, \\ Günther Unfer ${ }^{1}$, Bernhard Zeiringer ${ }^{1}$, Franz Greimel ${ }^{1}$, Stefan Auer ${ }^{1}$, Teresa Ferreira ${ }^{2}$ and \\ Stefan Schmutz ${ }^{1}$
}

1 Department of Water, Atmosphere and Environment, Institute of Hydrobiology and Aquatic Ecosystem Management, University of Natural Resources and Life Sciences, Vienna (BOKU), 1180 Vienna, Austria; melanie.haslauer@boku.ac.at (M.H.); guenther.unfer@boku.ac.at (G.U.);

bernhard.zeiringer@boku.ac.at (B.Z.); franz.greimel@boku.ac.at (F.G.); stefan.auer@boku.ac.at (S.A.); stefan.schmutz@boku.ac.at (S.S.)

2 Forest Research Center (CEF), Instituto Superior de Agronomia, University of Lisbon, 1349-017 Lisbon, Portugal; terferreira@isa.utl.pt

3 Center for Engineering Research and Innovation for Sustainability (CERIS), Instituto Superior Técnico, University of Lisbon, 1049-001 Lisbon, Portugal; miguelrmoreira@tecnico.ulisboa.pt (M.M.); isabelboavida@tecnico.ulisboa.pt (I.B.)

* Correspondence: daniel.hayes@boku.ac.at; Tel.: +43-147-654-81-223

Received: 15 February 2019; Accepted: 8 March 2019; Published: 14 March 2019

\begin{abstract}
Peak-operating hydropower plants are usually the energy grid's backbone by providing flexible energy production. At the same time, hydropeaking operations are considered one of the most adverse impacts on rivers, whereby aquatic organisms and their life-history stages can be affected in many ways. Therefore, we propose specific seasonal regulations to protect ecologically sensitive life cycle stages. By reviewing hydropeaking literature, we establish a framework for hydrological mitigation based on life-history stages of salmonid fish and their relationship with key parameters of the hydrograph. During migration and spawning, flows should be kept relatively stable, and a flow cap should be implemented to prevent the dewatering of spawning grounds during intragravel life stages. While eggs may be comparably tolerant to dewatering, post-hatch stages are very vulnerable, which calls for minimizing or eliminating the duration of drawdown situations and providing adequate minimum flows. Especially emerging fry are extremely sensitive to flow fluctuations. As fish then grow in size, they become less vulnerable. Therefore, an 'emergence window', where stringent thresholds on ramping rates are enforced, is proposed. Furthermore, time of day, morphology, and temperature changes must be considered as they may interact with hydropeaking. We conclude that the presented mitigation framework can aid the environmental enhancement of hydropeaking rivers while maintaining flexible energy production.
\end{abstract}

Keywords: sustainable hydropower; sub-daily flow fluctuations; peak-load energy production; pulsed flows; environmental flow; biologically sensitive periods; salmonids; Salmo salar; Salmo trutta; Thymallus thymallus

\section{Introduction}

Mountainous rivers are often subjected to sub-daily flow variations caused by peak-operating hydropower plants, which run their turbines according to the demand of the electricity market. These hydropower plants allow high flexibility in energy production, making them an essential part of the current and future electric grid as they can buffer periods of low energy availability of other renewables, such as wind or solar energy [1,2]. At the same time, hydropeaking entails numerous adverse ecological consequences and has therefore been described as "one of the most significant 
impacts on rivers downstream of dams" [3]. Fish communities, in particular, are severely threatened by hydropeaking [4]. Fish can be affected by changes in various components of the hydrograph, whereby the most common responses-stranding, drift, and dewatering of spawning grounds-are mostly related to up- and downramping rates [5,6], peak flow magnitude [5], and baseflow duration [7].

Considering the large capacity of existing storage hydropower plants [8], as well as new ones that are currently being planned and installed [9], it is imperative to develop appropriate and transferable management measures to mitigate these ecological impacts. Many structural (e.g., constructing retention basins) and operational (e.g., reducing flow fluctuation rates) mitigation measures have been proposed [10,11], but implementation remains difficult, among other issues, because of significant reductions in the energy yield when setting ecological thresholds [2,12]. Therefore, well-targeted mitigation measures have to be developed to avoid energy losses and to guarantee ecological efficiency.

Freeman et al. [13] argue that adverse effects can be minimized by either restoring vital features of the natural flow regime or by implementing a flow management scheme which avoids hydropower-induced habitat bottlenecks. Regarding the latter, multiple studies point out the need to identify critical flows, which include seasonal and diel considerations when determining operational mitigation strategies in rivers affected by hydropeaking [5,13-16]. To maintain self-sustaining fish populations in regulated water bodies, river management must take all life-history stages into account, especially during ecologically sensitive periods, when designing and implementing customized flow regimes [7]. This study aims to establish a framework for hydrological mitigation in rivers affected by hydropeaking, based on life cycle stages of fish and their relationship to key parameters of the hydrograph. We, therefore, describe the impacts of hydropeaking on each life cycle stage and propose critical aspects which must be considered when defining mitigation rules. We focus on salmonid fish as they are the most studied and most affected fish family regarding hydropeaking [17,18]. Nevertheless, many aspects of the presented mitigation concept can potentially be transferred to or adapted to the requirements of other taxa.

\section{Life Cycle Stage-Specific Mitigation Approach}

Within the life cycle of many salmonids, upstream spawning migrations are followed by the deposition of fertilized eggs in the gravel bed. In the following weeks, the eggs develop within the gravel substrate where, after hatching, the larvae (alevins) also stay until their yolk sack is absorbed. Afterwards, the fry emerge from the riverbed to find nursery habitats, e.g., along the shoreline for feeding and growth. As fish increase in size, they use different habitats. Once they reach sexual maturity, their life cycle starts over again $[19,20]$.

The literature indicates that each of these life cycle stages can show a distinct sensitivity to different aspects of the hydropeaking hydrograph, whereby reproduction and early life stages seem to be the most sensitive ones [15]. Thus, the key parameters for flow restoration will vary between the life cycle stages. In the following subchapters, we will therefore discuss the ecological effects of hydropeaking for each sensitive life stage, as well as establish a specific mitigation framework approach for each life cycle stage (Figure 1).

\subsection{Migration and Spawning}

River flow is a crucial factor for spawning-related activities [21]. In hydropeaking rivers, highly variable flows can influence, among other factors, migration, nest digging, and spawning behavior. Studies have shown that migration patterns of lake trout (Salmo trutta lacustris), as well as Chinook (Oncorhynchus tshawytscha) and pink salmon (O. gorbuscha), were correlated with the hydropeaking regime. Fish avoided migrating during changing flow magnitudes and they were able to cover greater distances on the days with peaking operations of lower amplitudes [22,23]. 


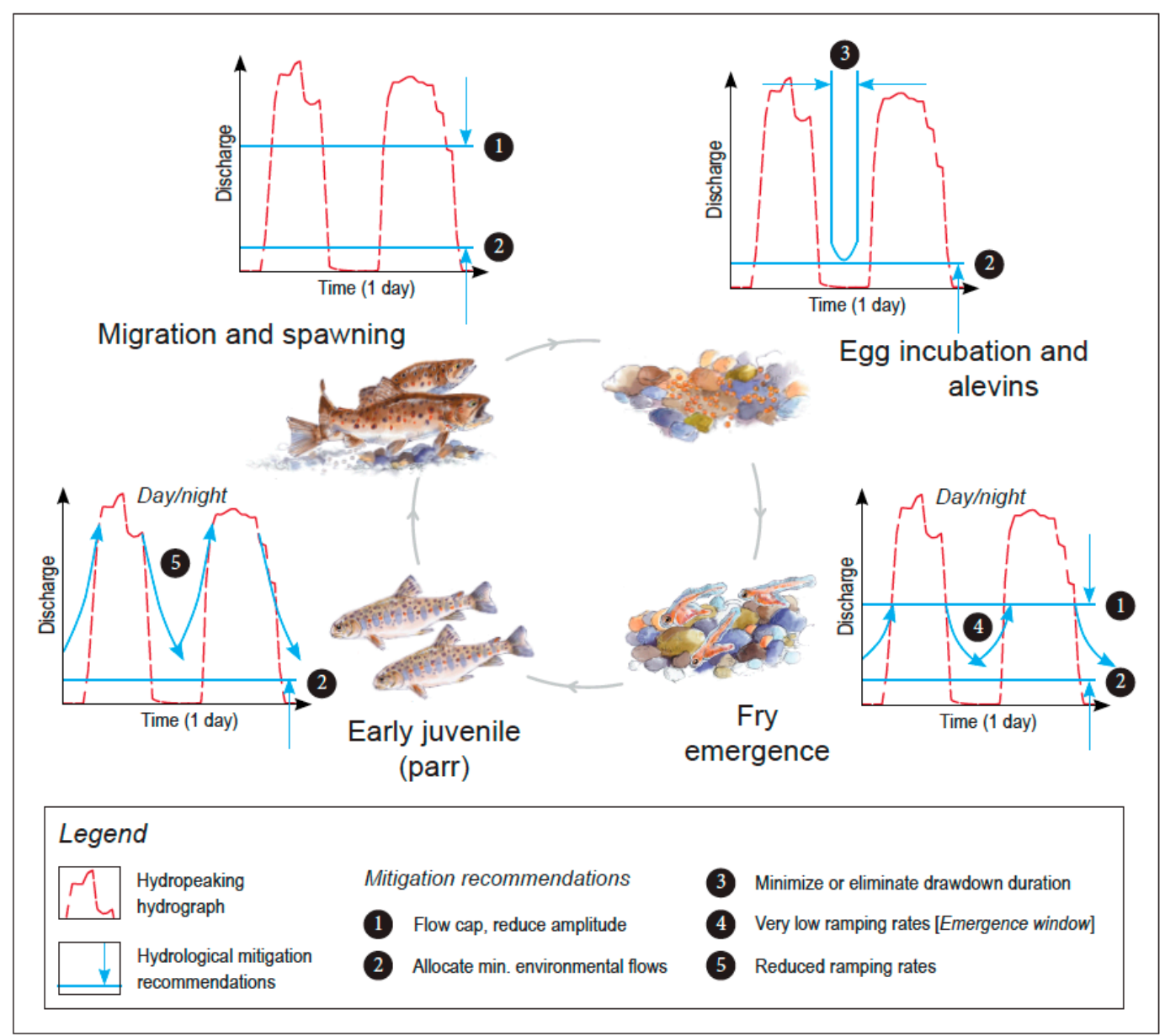

Figure 1. Life stage-specific hydropeaking flow rules: Conceptual framework for the sensitive life stage approach to mitigate the adverse impacts of hydropeaking. The dashed red lines represent a schematic daily hydropeaking hydrograph (two peaks and a baseflow phase), whereas the solid blue lines depict recommendations for hydrological restrictions to aid the environmental enhancement of hydropeaking rivers. "Day/night" indicates that restrictions might differ with time of day. For a detailed description, see Sections 2.1-2.4 (salmonid illustrations by DAB graphics, used with permission from The Wild Trout Trust Ltd, Waterlooville, England, www.wildtrout.org).

When fish are able to reach suitable reproduction areas, spawning can be interrupted by rapid flow fluctuations [16,24-26]. During downramping events, brown trout (S. trutta fario) stop preparing their redds [24] and brown trout and Atlantic salmon (S. salar) leave the spawning area if hydraulic conditions become unsuitable [26]. As soon as flows increase again, Atlantic salmon are highly motivated to continue redd preparation, and resume spawning once flows have returned to more stable conditions $[24,25]$, whereas brown trout take more time to re-engage in spawning-related activities [24].

To mitigate the effects of hydropeaking on migrating fish, it is therefore advantageous to release higher flows during migration periods [21]. Furthermore, during spawning, it is suggested that flows are kept relatively stable [16], at least for a sufficient duration to allow females to complete nest preparation and oviposition [26], which can take multiple hours to days for one spawning bed $[27,28]$, but several weeks for the entire population. The flow magnitude to enable these ecological functions can differ among geomorphic habitat units as it depends on the hydraulic conditions of the reach $[21,25]$ and the species present [26]. By allocating a steady environmental flow release during the peak spawning period (e.g., ca. four weeks for $S$. trutta), the ecological conditions can already be improved [29]. 
Although some salmonids tend to spawn during discharges greater than the median [30], the release of too high flows is not recommended if these water levels cannot be sustained throughout the incubation period [28]. At that stage, higher discharges could encourage nest-building in areas that will be at a higher risk of being dewatered between the hydropeaks later in the season. Instead, flow caps, i.e., upper peak limits, should be implemented [21,26,31-33], as the survival of intragravel life stages is linked to redd site selection during the spawning period.

\subsection{Intragravel Life Cycle Stages: Egg Incubation and Alevins}

In hydropeaking rivers, intragravel life cycle stages can be predominantly influenced through either siltation of sediments [34,35], scouring [21,35], or dewatering of spawning grounds [21,31,32]. In the winter, mountainous rivers are characterized by an extended low baseflow period. During this season, hydropeaking rivers, however, often exhibit relatively high flow fluctuations. This operational scheme leads to higher flow amplitudes in winter compared to summer [36,37].

As salmonids deposit their eggs in the gravel bed, siltation may reduce hatching success by affecting interstitial water flow [38,39]. It has been suggested that hydropeaking is a governing factor regarding fine sediment dynamics in gravel-bed rivers, as hydropeaking can change the fine sediment composition of both surface and subsurface layers [40]. Indeed, a recent study [34] found that ramping zones exhibited significant surface clogging due to a continuous accumulation of fines. In contrast, permanently inundated areas contained little or no fine sediment infiltration into the riverbed's surface layers as fines are subject to transport. Interestingly, the hydropeak magnitude itself, expressed as the peaking ratio, was not related to fine sediment infiltration rates [34]. It seems, therefore, that the spawning ground position in the riverbed (see Section 2.1) can influence hatching success through the effect of sediment sizes.

It is expected that, due to nest-building of female salmonids, spawning ground stability is increased as sediments are sorted and redds, therefore, feature coarser substrate surfaces than unspawned beds through winnowing of fines. Despite this coarsening effect, however, studies [41] have demonstrated that redds are more unstable than unspawned beds. For example, redds exhibited a $12-37 \%$ lower grain resistance to motion, as well as a $13-41 \%$ higher boundary shear stress for the same flows in comparison to unspawned beds. Also, bed-average shear stress was significantly reduced [41]. Although studies indicate that salmonid spawning usually takes place in locations with less excess shear stress [21], hydropower peak flows may enhance the risk of embryo mortality as redds are more likely to be eroded than the surrounding gravel bed [21,41]. However, although scour has been cited as a potentially adverse effect, no study has yet quantified its impact magnitude. Furthermore, the scouring potential also depends on the peak flow magnitude. Unfer et al. [42] demonstrated that only flow magnitudes larger than half the size of mean annual high flow events were able to substantially erode sediments in the Alpine Ybbs River, Austria. The risk of egg erosion due to hydropeaking may, therefore, be rather case-specific [35] and may only occur in rivers with a high peaking magnitude.

If spawning occurs during peak flow periods, the drawdown to winter baseflows between peaks could lead to the dewatering of spawning grounds, which is a significant concern as it can result in the mortality of eggs and alevins [31,43]. It has been demonstrated that salmonid eggs are generally rather robust to dewatering and can survive extended time frames without inundation, provided that they are kept moist, are not subjected to extreme temperatures (i.e., freezing or heating) exceeding incubation tolerances, and receive sufficient oxygen through the influx of air into the interstitial spaces [31,43-46]. In contrast, newly hatched alevins (eleutheroembryos) are less tolerant to redd desiccation and may die within $4-12 \mathrm{~h}$ of dewatering, whereas pre-emergent alevins are considered the most sensitive intragravel life stage [44-46]. Since pre-emergent alevins depend on gills for respiration, dewatering events $<1 \mathrm{~h}$ lead to very high $(>96 \%)$ mortality rates [44], which can have profound impacts on fish populations. However, groundwater upwelling might attenuate apparent adverse effects where available $[21,43,47]$. 
To prevent the mortality of intragravel life stages, it is recommended that power production is adapted to discourage fish from spawning in shallow water which will later fall dry (see Section 2.1). Additionally, the duration of hydropower production stops should be minimized. Also, the provision of enhanced minimum flows during this critical development period can help to reduce the difference between incubation and spawning flows [32,43,48,49]. During the egg incubation, limited redd dewatering through the hydropower plant operation might not entail complete losses in some cases [16,32], such as in the presence of local groundwater upwellings and at temperatures above freezing [43]. However, considering that spawning can occur over an extended period and that multiple species can be present in the same river, allowing limited redd dewatering is not recommended since alevins, which require continuous inundation [7], may be present throughout the entire time [16].

\subsection{Fry Emergence and Early Juvenile Development}

After alevins have absorbed the major portion of their yolk sack, they emerge as fry from the substrate $[19,20]$. During this early ontogenetic development, they are very susceptible to pulsed-flow operations as they utilize high-risk habitats in the ramping zone and have little swimming capacities, entailing drift and stranding of individuals [5,6,50-53]. In the Saltdalselv River, Norway, high flows during the alevin and fry stage significantly increased the mortality of Atlantic salmon and brown trout [54]. Similarly, fry recruitment was negatively related to the number of hydropeaks during the emergence period in the Lez River, France [55].

\subsubsection{Thresholds for Impact Mitigation}

Rapid flow reductions due to downramping can increase the stranding probability of fish through quickly receding water levels, causing sub-lethal impacts or direct fish mortality $[16,18]$. Studies have shown that stranding is species- and size-selective, whereby recently emerged fry are the most vulnerable life-history stage $[15,52,56,57]$. This finding is supported by the analysis of ten-year flow downramping monitoring data of Canadian rivers, showing that the highest stranding probabilities occur from May to August when juveniles inhabit nearshore areas which are likely to be dewatered [50]. Field surveys at the Drava River, Austria, revealed 50-500 stranded larvae of European grayling (Thymallus thymallus) per $100 \mathrm{~m}$ shoreline after single hydropeaking events [58]. In general, a reduction of ramping rates to $<0.17-0.25 \mathrm{~cm} \cdot \mathrm{min}^{-1}$ is related to less stranding and, therefore, a greater probability of attaining a higher fish ecological status [4,59]. On a more detailed level, experimental studies indicate that, during fry emergence, mitigation thresholds on downramping velocity must be rather low to prevent stranding, e.g., $0.23-0.31,0.2$, or $0.1 \mathrm{~cm} \cdot \mathrm{min}^{-1}$ for larvae of Atlantic salmon, European grayling, or brown trout, respectively $[6,52,56,60]$.

Early juvenile life stages are also susceptible to downstream displacement [52], especially during nighttime hydropeaking [5]. However, little is known about the long-term population effects caused by drifted fish. Nevertheless, a reduction of drift is advisable. Therefore, a lowered upramping rate and a reduced peak amplitude are recommended [5,29].

\subsubsection{Emergence Window Establishment}

Generally, it is advisable to stabilize the flow as much as possible in the early growing season [59]. Alfredsen et al. [33] suggest introducing a cap flow and restricting rapid flow changes during swim-up. Since fry are especially vulnerable to sub-daily flow fluctuations and are present only at specific periods of the year [16,52], a feasible management approach is to define temporal 'emergence windows' where stringent thresholds, e.g., regarding downramping to prevent stranding, are enforced [8,15,52,61]. These emergence windows should start with the highly sensitive alevin phase [44-46] just before fry emerge from the gravel, whereas the length of the window depends on the growth, which is mainly related to temperature. Stranding experiments $[52,56]$ indicate that the temporal duration must be around two weeks for European grayling and four weeks for brown trout, as grayling improves its reactivity to drawdown events quicker than brown trout. Even though these two species spawn at 
different periods (brown trout in fall/winter and European grayling in late winter/spring), their larvae occur in the same season (mid-April to early August) due to their temperature-dependent egg development [62], underlining the feasibility of the emergence window approach. Approximate start and end dates can be calculated with temperature data if the time of spawning is known $[19,33,62]$. For example, Figure 2 depicts a first river-specific assessment of emergence windows for brown trout and European grayling for selected Austrian hydropeaking rivers based on information from anglers. Due to the imprecise data situation, the proposed time frames are still rather long and represent only a rough estimate. It would be possible to confine the time period of the emergence window by assessing the exact emergence time through electrofishing surveys and modeling based on spawning time and day degrees of egg development. The results would allow the deduction of a river-specific period of early fish life cycle development by analyzing the water temperature of the sampling year. This information could then possibly be transferred to the following years. Another feasible approach would be to visually observe (stranding of) larvae from the end of April onwards to determine a river reach-specific emergence window. In rivers with different species of Pacific salmon, the implementation might be more difficult due to varying emergence periods [48].

\# Brown trout $\quad$ Temporal overlapping emergence $\quad$ European grayling

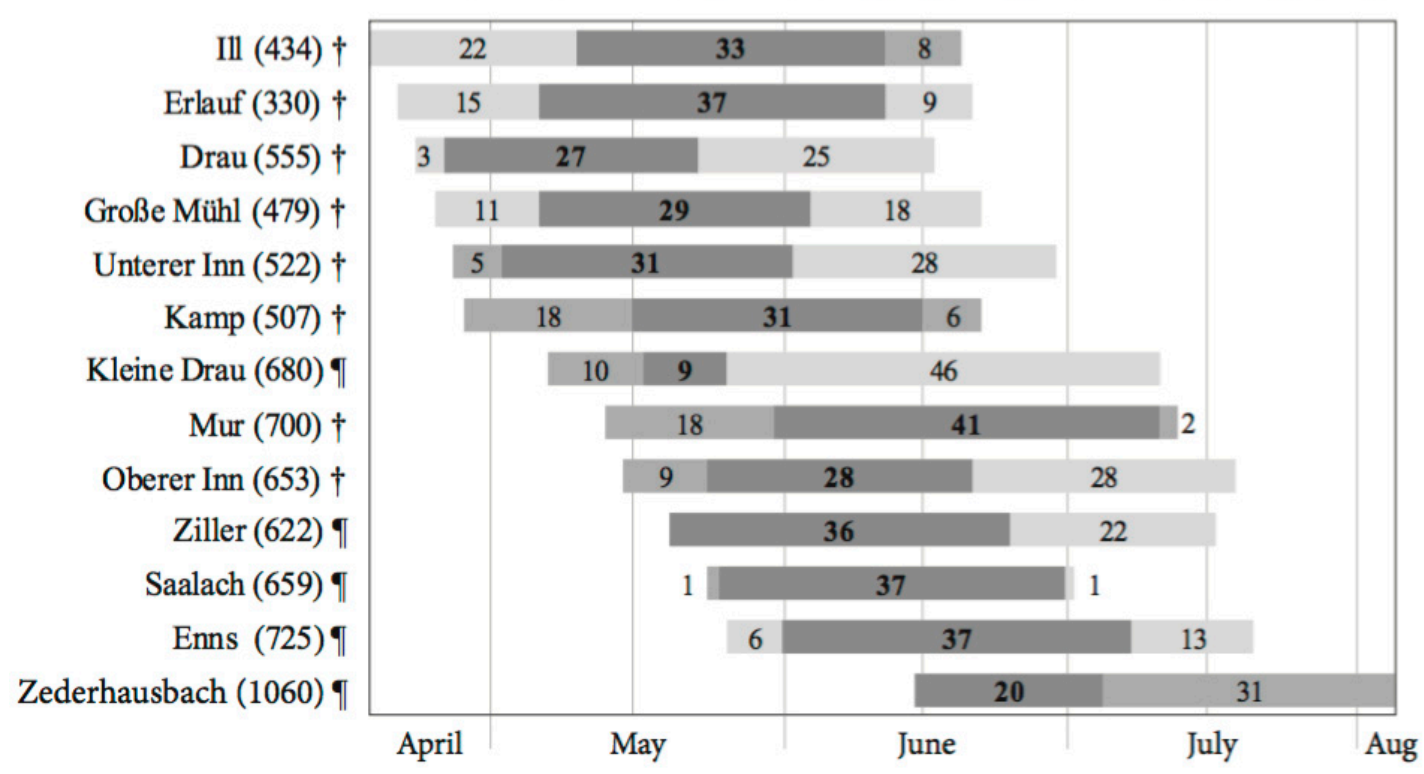

Figure 2. Emergence window proposal for brown trout (Salmo trutta) and European grayling (Thymallus thymallus) in selected Austrian hydropeaking rivers. The depicted time frame is based on temperature-dependent models for predicting the time of median hatch as reported in the literature. For the brown trout, we used the formula from Crisp [19], and for the grayling, the one published by Jungwirth \& Winkler [62]. The begin and end of the spawning time for each species was reported by anglers and served as the starting point for the calculations, which were then based on daily mean temperature data of ten years (gauging stations of Austrian Hydrographic Service; meters above the Adriatic in brackets; $+=$ metarhithral (i.e., lower trout) fish region; $\mathbb{I I}=$ hyporhitrhral (i.e., grayling) fish region). Emergence of brown trout and European grayling takes place between mid-April and early August, whereby the emergence windows of both species also partially overlap. The duration of the emergence periods is displayed in the bars as a mean number of days.

\subsection{Parr to Adults}

Parr are also vulnerable to stranding and drift, whereby the risk is reduced as they grow in size and increase their swimming performance, and additionally shift to deeper habitats away from the dewatered ramping zone [53]. Therefore, less restrictive ramping rates-in comparison to fry-can be sufficient $[5,15,16,52,56,57]$. However, since stranding probability is also determined by other factors 
aside from downramping velocity (e.g., wetted history, baseflow conditions, time of day), these must be considered in the establishment of mitigation rules as well [15]. For example, before a large flow reduction, lower reductions are recommended prior to higher ones to shorten the wetted history [50]. Furthermore, the time of day can play a significant role. Some studies report that, during summer, young-of-year brown trout and grayling are less vulnerable during the day and more susceptible to stranding during the night $[5,56,60]$. In contrast, during colder water temperatures in fall or winter, higher stranding is reported for daytime than for nighttime hours for brown trout, rainbow trout (O. mykiss), Atlantic salmon, and Coho salmon (O. kisutch) $[6,63,64]$. Both can be related to diel behavior changes [65] as, for example, in winter, salmonids are passive during the day and active in the night $[64,66]$. Therefore, ramping rate restrictions should be more stringent during darkness in summer and during daylight hours in winter. It must be noted, however, that Connor \& Pflug [48] have reported exactly the opposite as the above cited studies. They recommend limiting downramping to nighttime hours between the emergence and outmigration period. However, this focus on daytime mitigation might be because, in the Skagit River case study, daytime flow reduction represented $89 \%$ of all events during the peak stranding period [48]. Differences in stranding or drift might also be triggered by other factors, such as water turbidity or predation. In this regard, more research is necessary. In the meantime, however, case-specific solutions are required.

Regarding fish movement patterns during hydropeaking, Robertson et al. [67] found that, in winter, flow neither affected fish activity or habitat use, nor displaced Atlantic salmon parr. Only in late winter was fish activity reduced during high flows in the night. Similarly, Stickler et al. [68] did not detect differences in fish activity between high and low flows, which was also confirmed by Berland et al. [69], who analyzed parr movement in September related to river flow and ramping rate. Therefore, it can be concluded that, for the most part, hydropeaking does not affect salmonid fish movements in winter. In contrast, in summer, juvenile Atlantic salmon show higher movement rates in hydropeaking channels than in control channels [70], a pattern which was also confirmed for 1+ salmon in a telemetry study during spring [71]. Considering the increase in juvenile fish movement during summer in combination with inhibited feeding during peak flows [72], it is not surprising that, at the end of the growing season, fish that were subjected to fluctuating flows had a lower body fat and body mass than fish subjected to stable flows. Although the effects were small [70] or, in some cases, not detectable [58], the long-term impact on the population can be potentially many times higher. Simulating the effects of stranding on the salmon population in the Dale River, Norway, Sauterleute et al. [73] conclude that the most substantial adverse effect on the population abundance in hydropeaking rivers is related to the stranding of older juvenile fish during winter daylight conditions, suggesting that the stranding of salmon at this life cycle stage is likely to have greater population impacts than that of earlier life cycle stages. Furthermore, the stored energy reserves from the summer may be a critical factor in determining overwinter survival $[74,75]$.

\section{Discussion}

Future sustainable hydropower management relies on the development of well-informed and targeted mitigation strategies [76]. Here, we propose a management framework to mitigate adverse impacts of hydropeaking operations on salmonid fish, whereby we advocate that, in each season, the most sensitive life cycle stage should be the decisive element regarding peaking restrictions. Figure 1 constitutes a graphical depiction of this mitigation framework approach by illustrating a hydropeaking hydrograph scheme (two peaks and a baseflow phase), as well as the above-described flow restrictions necessary for aiding the environmental enhancement of hydropeaking rivers (i.e., depending on season: implementing flow caps, allocating minimum environmental flows, decreasing the flow ratio, minimizing dewatering durations or prohibiting dewatering, or lowering ramping rates). Alfredsen et al. [33] used a similar approach by defining flow blocks for environmental flow allocation to meet the need of Atlantic salmon life stages in the Daleelva River, Norway. Due to sub-daily flow fluctuations, hydropeaking represents a specific sub-group within environmental flow in rivers 
where hydrological stress on aquatic ecosystems is intensified. Therefore, there is a need to develop qualitative seasonal flow rules for hydropeaking rivers as well. Here, we focused solely on salmonid species as most available literature deals with this fish family $[15,17,18]$. Many aspects of the presented framework can potentially be transferred to other taxa as well, but further research must be conducted on other fish families, such as cyprinids, to validate these suggestions.

Literature indicates that different elements of the hydrograph can be tweaked to improve the survival of the respective life stages (Figure 1), whereby the temporal windows must be adapted to the local river conditions. However, mitigation thresholds (e.g., for baseflow, peak flow, ramping rate) depend not only on the life cycle stage, but also on the respective species present, as well as the time of day. Nevertheless, only a few quantitative thresholds have been proposed so far, highlighting the need for further research [15]. Therefore, for the most part, we were only able to extract qualitative/conceptual mitigation recommendations. Related to that is the question of which life cycle stage is the most sensitive to sub-daily flow fluctuations regarding having the greatest adverse effect for the fish population.

The field of environmental flow has progressed towards advocating function- and process-oriented flows $[14,77]$, thereby moving away from static water allocations and towards dynamic environmental flows to sustain ecological communities $[14,78]$. Considering that hydropeaking rivers are essentially residual flow stretches-just that, in addition to water abstraction, they are also highly impacted by sub-daily flow fluctuations [79] — mitigation measures for hydropeaking must be incorporated into the seasonal and inter-annual environmental flow requirements. Therefore, scientific advancement must merge the concepts of dynamic environmental flow and hydropeaking mitigation to propose sustainable and holistic management recommendations for flow-altered watercourses.

\subsection{The Effects of River Hydromorphology}

Many studies indicate that the ecological effects related to hydropeaking, e.g., stranding or drift, are also dependent on river morphology, including bank slope, grain size distribution, or cover $[5,12,64,80]$. Higher stranding, for example, occurs more frequently on lower gradient bars than on steeper banks [64], but steeper banks provide less larval and juvenile habitats. Coarse substrate will trap fish more during dewatering than small grain sizes [80]. Due to water retention, vertical dewatering speed reduces with distance to the hydropower outlet, therefore lowering the stranding risk along the river's course [3,59]. In morphologically unfavorable river sections (e.g., in channelized rivers), spawning, larval, and juvenile habitats are often lacking, whereas in nature-like channels, ramping rate reductions may improve the fish ecological status [4]. Hauer et al. [3,80] highlight that the changes in wetted width between baseflow and peak flow and, thereto related, changes in the lateral ramping velocity depend on the river's channel bar form, as well as the baseflow magnitude (see also [81]). Depending on this combination, a $<1: 2$ peaking ratio can have a greater impact on cross-sectional wetted width than a 1:5 ratio [80]. Therefore, Halleraker et al. [59] recommend different dewatering thresholds for distinct flow ranges in the Surna River, Norway, where more stringent flow limits are needed for lower discharges than for high ones [50,59].

Self-forming gravel bars (e.g., point bars or alternating gravel bars) have been identified as both suitable structures for young-of-year trout, as well as areas of reduced stranding risk due to self-forming backwater habitats [80,82]. These findings underline the need to combine hydrological rehabilitation with morphological restructuring measures to minimize the ecological impact of hydropeaking $[8,12,80,83]$. Next to river restoration measures, connectivity to tributaries may also play an essential role in supporting fish populations in hydropeaking rivers. Tributaries often exhibit more stable hydrological conditions and less risk of erosion and, therefore, may provide suitable spawning and rearing habitats for fish [3]. 


\subsection{The Effects of Sub-Daily Temperature Changes}

Another abiotic factor that can influence the effects of hydropeaking on fish is water temperature, as the release of pulsed flows is often coupled with thermal changes (i.e., thermopeaking) [84]. The ecological effects of long-term thermal alterations below dams have received some attention [85], whereas less is known about the reaction of eggs or fish to sub-daily thermopeaking. Therefore, further analyses have to be performed to study potential effects in detail [4].

Research has shown that both hydropeaking and thermopeaking can influence macroinvertebrate communities [86]. Although we did not integrate macroinvertebrates into our conceptual mitigation framework, this group should be included in more holistic approaches in the future, not only because benthic communities are an essential food source for fish, but also because they are an indispensable aspect of functioning river systems [87]. Also, as benthic dwellers, macroinvertebrates are particularly sensitive to sediment composition and habitat conditions in the river bed [34].

\subsection{Other Hydropeaking-Related Impacts}

Aside from thermopeaking, two other hydropeaking-related impacts have recently been described. 'Saturopeaking' refers to fluctuations of gas saturation which follow the rapid, periodic, and frequent pattern of hydropeaking operations [88], and 'soundpeaking' to hydropeaking-induced changes in river soundscapes, whereby sound pressure levels can be strongly correlated with turbine discharge [89]. Although some guidelines exist for supersaturation (i.e., when total dissolved gases saturation exceeds $100 \%$ ) [88], possible ecological effects of saturopeaking and soundpeaking in hydropeaking rivers still remain to be studied [15], as well as the combined effects of these pressures.

\subsection{Achieving Hydrological Mitigation Measures and Their Economic Implications}

To achieve mitigation, either structural or operational measures can be utilized [10,12], whereby similar positive hydrological changes in the tailrace can be obtained, e.g., by changes in the power plant operation scheme, as well as through the construction of retention basins [2,90]. Considering the economic implications, however, these two approaches show quite different outcomes [2]. Hydropeaking power plants operate competitively according to immediately changing market prices, which means that the quicker their turbines can be turned on and off, the higher the economic benefits are. Therefore, operational restrictions affect the ability to produce highly valuable peak energy [2,12,91], especially if less favorable turbines types are installed [92] or the water availability imposes constraints. In contrast, peak retention basins might initially require significant investment costs, but, according to Person et al. [12], they show high beneficial ecological effects by reducing sub-daily flow fluctuations at reasonable costs. Since retention basins allow ramping rate reductions, they may be especially useful for applying seasonal flow rules during ecologically sensitive periods [90]. Only limited space availability may be the major problem for the construction of such basins. In contrast, instream velocity refuges such as deflectors require less lateral space [93]. In the very critical larval phase, a combination of compensation reservoirs and altered operational management might be most effective by avoiding over-sized reservoirs. Currently, the feasibility of the air cushion underground reservoir (ACUR) technology [94] to mitigate environmental hydropeaking effects is being tested in the European project "HydroFlex" [95].

\subsection{Limitations of This Study and Research Needs}

In recent years, researchers have established a firm knowledge basis regarding general fish ecological topics, such as the response of different salmonid life-history stages to different environmental parameters, including water flow, temperature, or substrate conditions $[96,97]$ (Table 1). Of course, there are questions which still remain to be answered [96,98]. In the last years, hydropeaking research has significantly advanced in terms of scientific output [99], and this increasing amount of information has allowed us to formulate the presented mitigation framework (Figure 1). Nevertheless, 
although such a life cycle stage approach constitutes the most up-to-date framework on hydropeaking mitigation, it is to be expected that future studies will significantly expand the present knowledge base regarding the effects of hydropeaking on various life cycle stages, and proposed flow management recommendations may have to be adapted. Therefore, Table 1 presents a knowledge matrix which highlights crucial research areas in the field of hydropeaking impact and mitigation. Future research will, among other goals, have to better quantify the effects of hydropeaking on spawning activities and egg incubation phases (especially with regard to scour or siltation, and sub-daily temperature changes), and investigate impacts on the fish population and community level, including studying the effects of hydropeaking on the food web (e.g., between nutrients, periphyton, macroinvertebrates, and fish). 
Table 1. Knowledge matrix on the general fish ecological and hydropeaking research conducted on salmonids. We categorized life-history stages (and their activity) into three classes: " -" = no or hardly any studies conducted; " \pm " = some research is published, but knowledge gaps remain; " + " $=$ extensive studies have been conducted. Literature examples of each research field are given.

\begin{tabular}{|c|c|c|c|c|c|c|}
\hline \multicolumn{2}{|c|}{ Life-History Stage (and Activity) } & \multirow{2}{*}{$\begin{array}{c}\text { Ecological } \\
\text { Research } \\
+ \\
\end{array}$} & \multirow{2}{*}{$\begin{array}{c}\begin{array}{c}\text { Literature } \\
\text { Example(s) }^{1}\end{array} \\
{[20,98,100-102]} \\
\end{array}$} & \multirow{2}{*}{$\begin{array}{c}\text { Hydropeaking } \\
\text { Research }^{2} \\
-\end{array}$} & \multirow{2}{*}{$\begin{array}{c}\text { Literature } \\
\text { Example(s) }\end{array}$} & \multirow[t]{2}{*}{ Particularities on Hydropeaking Studies } \\
\hline Spawning & Migration & & & & & \\
\hline & Behavior $^{3}$ & + & {$[27,102,103]$} & - & [24-26] & \\
\hline \multirow[t]{2}{*}{$\begin{array}{l}\text { Intragravel life } \\
\text { stages }\end{array}$} & Egg incubation & + & {$[19,20,101]$} & \pm & {$[31,43-46]$} & $\begin{array}{l}\text { Aside from studies on short- or long-term } \\
\text { desiccation, information on repeated wetting and } \\
\text { drying is largely missing for different species. }\end{array}$ \\
\hline & Alevin & + & {$[19,20,98]$} & - & {$[44]$} & \\
\hline \multirow[t]{2}{*}{$\begin{array}{l}\text { Young-of-the-year } \\
(0+)\end{array}$} & Fry & + & {$[97,98]$} & \pm & {$[52,55-57]$} & $\begin{array}{l}\text { Only studies regarding few selected species, } \\
\text { topics mostly restricted to stranding and drift. }\end{array}$ \\
\hline & Parr & + & {$[19,20,104]$} & \pm & {$[5,6,70,71]$} & $\begin{array}{l}\text { Only studies regarding few selected species, } \\
\text { topics mostly restricted to drift, stranding, } \\
\text { movements, habitat use, and growth. }\end{array}$ \\
\hline Juvenile & $1+$ fish (smolt) & + & {$[19,102,104,105]$} & - & {$[61,106]$} & \\
\hline Adult & $2+$ fish & + & [105] & - & [107] & \\
\hline
\end{tabular}

${ }^{1}$ We focused on reviews or books, as they provide the best overviews of the field of research. ${ }^{2}$ Mostly regarding the impacts of hydropeaking. For a recent review on hydropeaking mitigation, see Moreira et al. [15], who summarized the current status (research and legislation) and presented research needs. ${ }^{3}$ Common conditions contributing to spawning behavior include: Nest selection, building, probing, completion and oviposition, and covering [27] 


\section{Conclusions}

Research shows that fish are sensitive to hydrological modifications, especially sub-daily flow fluctuations, which can influence each life cycle stage through various components of the hydropeaking hydrograph. We reviewed the literature to understand how hydropeaking influences each life cycle stage of salmonids. This approach allowed us to conceptualize a qualitative mitigation framework which is based on seasonal flow regulations to protect ecologically sensitive life cycle stages (Figure 1), whereby the following flow rules are recommended: During migration and spawning, flows should be kept relatively stable, and a flow cap should be implemented to prevent the dewatering of spawning grounds during intragravel life stages. While eggs may be comparably tolerant to dewatering, post-hatch stages are very vulnerable, which calls for minimizing or eliminating the duration of drawdown situations. Especially emerging fry are extremely sensitive to sub-daily flow fluctuations. Therefore, a temporally-limited 'emergence window', where stringent thresholds on ramping rates are enforced, is proposed. As fish grow in size, they become less vulnerable. Therefore, less restrictive ramping rates (in comparison to fry) can be acceptable. In all seasons, adequate environmental flows shall be allocated. Furthermore, when setting mitigation thresholds, interacting effects of daytime, river morphology, and water temperature also have to be considered.

The implementation of these seasonal restriction guidelines will not only counter possible hydropower-induced population bottlenecks but has the potential to entail less significant reductions in energy yield compared to all-year round hydrological limits [76]. Nevertheless, further research is necessary to evaluate the ecological effectiveness of the proposed concept and to quantify exact thresholds for different species, life cycle stages, seasons, and time of day in distinct river types [15] while minimizing flexible energy yield reductions in the implementation thereof.

Author Contributions: Conceptualization, D.S.H.; methodology, D.S.H., M.M., I.B., G.U., and B.Z.; investigation: D.S.H., M.M., and M.H.; writing—original draft preparation, D.S.H.; writing-review and editing, D.S.H., M.M., I.B., M.H., G.U., B.Z., F.G., S.A., T.F., and S.S.; visualization, D.S.H. and M.H.; supervision, S.S. and T.F.; project administration, F.G.; funding acquisition, T.F., F.G., and S.S.

Funding: D.S.H. and M.M. benefited from a Ph.D. grant from Fundação para a Ciência e a Tecnologia, Portugal (FCT) (PD/BD/114440/2016 and PD/BD/114336/2016). CEF is a research unit funded by FCT (UID/AGR/00239/2013). Some of the proposed life cycle measures were developed within the SuREmMa project (Sustainable River Management-Energiewirtschaftliche und umweltrelevante Bewertung möglicher schwalldämpfender Maßnahmen), which has been sponsored by the Austrian hydropower companies and the Federal Ministry of Agriculture, Forestry, Environment and Water Management via the COMET research program (alpS).

Acknowledgments: Supported by BOKU Vienna Open Access Publishing Fund.

Conflicts of Interest: The authors declare no conflict of interest. The funders had no role in the design of the study; in the collection, analyses, or interpretation of data; in the writing of the manuscript, or in the decision to publish the results.

\section{References}

1. Ashraf, F.B.; Haghighi, A.T.; Riml, J.; Alfredsen, K.; Koskela, J.J.; Kløve, B.; Marttila, H. Changes in short term river flow regulation and hydropeaking in Nordic rivers. Sci. Rep. 2018, 8, 17232. [CrossRef] [PubMed]

2. Greimel, F.; Neubarth, J.; Zeiringer, B.; Hayes, D.S.; Haslauer, M.; Führer, S.; Auer, S.; Höller, N.; Hauer, C.; Holzapfel, P.; et al. Sustainable River Management in Austria. In Proceedings of the 12th International Symposium on Ecohydraulics 2018, Tokyo, Japan, 19-24 August 2018; p. 4.

3. Hauer, C.; Holzapfel, P.; Leitner, P.; Graf, W. Longitudinal assessment of hydropeaking impacts on various scales for an improved process understanding and the design of mitigation measures. Sci. Total Environ. 2017, 575, 1503-1514. [CrossRef] [PubMed]

4. Schmutz, S.; Bakken, T.H.; Friedrich, T.; Greimel, F.; Harby, A.; Jungwirth, M.; Melcher, A.; Unfer, G.; Zeiringer, B. Response of Fish Communities to Hydrological and Morphological Alterations in Hydropeaking Rivers of Austria. River Res. Appl. 2015, 31, 919-930. [CrossRef] 
5. Auer, S.; Zeiringer, B.; Führer, S.; Tonolla, D.; Schmutz, S. Effects of river bank heterogeneity and time of day on drift and stranding of juvenile European grayling (Thymallus thymallus L.) caused by hydropeaking. Sci. Total Environ. 2017, 575, 1515-1521. [CrossRef] [PubMed]

6. Saltveit, S.J.; Halleraker, J.H.; Arnekleiv, J.V.; Harby, A. Field experiments on stranding in juvenile Atlantic salmon (Salmo salar) and brown trout (Salmo trutta) during rapid flow decreases caused by hydropeaking. Regul. Rivers Res. Manag. 2001, 17, 609-622. [CrossRef]

7. Casas-Mulet, R.; Alfredsen, K.; Brabrand, A.; Saltveit, S.J. Hydropower operations in groundwater-influenced rivers: Implications for Atlantic salmon, Salmo salar, early life stage development and survival. Fish. Manag. Ecol. 2016, 23, 144-151. [CrossRef]

8. Greimel, F.; Neubarth, J.; Fuhrmann, M.; Führer, S.; Habersack, H.; Haslauer, M.; Hauer, C.; Holzapfel, P.; Auer, S.; Pfleger, M.; et al. SuREmMa, Sustainable River Management_Energiewirtschaftliche und umweltrelevante Bewertung möglicher schwalldämpfender Maßnahmen; Bundesministerium für Land- und Forstwirtschaft, Umwelt und Wasserwirtschaft: Vienna, Austria, 2017.

9. IHA. Hydropower Status Report 2017; International Hydropower Association: London, UK, 2017.

10. Bruder, A.; Tonolla, D.; Schweizer, S.P.; Vollenweider, S.; Langhans, S.D.; Wüest, A. A conceptual framework for hydropeaking mitigation. Sci. Total Environ. 2016, 568, 1204-1212. [CrossRef]

11. Greimel, F.; Schülting, L.; Wolfram, G.; Bondar-Kunze, E.; Auer, S.; Zeiringer, B.; Hauer, C. Hydropeaking Impacts and Mitigation. In Riverine Ecosystem Management; Schmutz, S., Sendzimir, J., Eds.; Springer: Berlin, Germany, 2018; pp. 91-110, ISBN 978-3-319-73250-3.

12. Person, E.; Bieri, M.; Peter, A.; Schleiss, A.J. Mitigation measures for fish habitat improvement in Alpine rivers affected by hydropower operations. Ecohydrology 2014, 7, 580-599. [CrossRef]

13. Freeman, M.C.; Bowen, Z.H.; Bovee, K.D.; Irwin, E.R. Flow and habitat effects on juvenile fish abundance in natural and altered flow regimes. Ecol. Appl. 2001, 11, 179-190. [CrossRef]

14. Hayes, D.S.; Brändle, J.M.; Seliger, C.; Zeiringer, B.; Ferreira, T.; Schmutz, S. Advancing towards functional environmental flows for temperate floodplain rivers. Sci. Total Environ. 2018, 633, 1089-1104. [CrossRef]

15. Moreira, M.; Hayes, D.S.; Boavida, I.; Schletterer, M.; Schmutz, S.; Pinheiro, A. Ecologically-based criteria for hydropeaking mitigation: A review. Sci. Total Environ. 2019, 657, 1508-1522. [CrossRef]

16. Hunter, M.A. Hydropower Flow Fluctuations and Salmonids: A Review of the Biological Effects, Mechanical Causes and Options for Mitigation; Department of Fish and Wildlife: Olympia, WA, USA, 1992.

17. Melcher, A.H.; Bakken, T.H.; Friedrich, T.; Greimel, F.; Humer, N.; Schmutz, S.; Zeiringer, B.; Webb, J.A. Drawing together multiple lines of evidence from assessment studies of hydropeaking pressures in impacted rivers. Freshw. Sci. 2017, 36, 220-230. [CrossRef]

18. Nagrodski, A.; Raby, G.D.; Hasler, C.T.; Taylor, M.K.; Cooke, S.J. Fish stranding in freshwater systems: Sources, consequences, and mitigation. J. Environ. Manag. 2012, 103, 133-141. [CrossRef]

19. Crisp, D.T. Trout and Salmon: Ecology, Conservation and Rehabilitation; Fishing News Books, Blackwell Science: Oxford, UK, 2000.

20. Quinn, T.P. The Behavior and Ecology of Pacific Salmon and Trout; University of Washington Press: Seattle, WA, USA, 2005.

21. Malcolm, I.A.; Gibbins, C.N.; Soulsby, C.; Tetzlaff, D.; Moir, H.J. The influence of hydrology and hydraulics on salmonids between spawning and emergence: Implications for the management of flows in regulated rivers. Fish. Manag. Ecol. 2012, 19, 464-474. [CrossRef]

22. Mendez, R. Laichwanderung der Seeforelle im Alpenrhein; Swiss Federal Institute of Aquatic Science and Technology: Dübendorf, Switzerland, 2007.

23. Jones, N.E.; Petreman, I.C. Environmental Influences on Fish Migration in a Hydropeaking River. River Res. Appl. 2015, 31, 1109-1118. [CrossRef]

24. Haas, C.; Zinke, P.; Vollset, K.W.; Sauterleute, J.; Skoglund, H. Behaviour of spawning Atlantic salmon and brown trout during ramping events. J. Appl. Water Eng. Res. 2016, 4, 25-30. [CrossRef]

25. Moir, H.J.; Gibbins, C.N.; Soulsby, C.; Webb, J.H. Discharge and hydraulic interactions in contrasting channel morphologies and their influence on site utilization by spawning Atlantic salmon (Salmo salar). Can. J. Fish. Aquat. Sci. 2006, 63, 2567-2585. [CrossRef]

26. Vollset, K.W.; Skoglund, H.; Wiers, T.; Barlaup, B.T. Effects of hydropeaking on the spawning behaviour of Atlantic salmon Salmo salar and brown trout Salmo trutta. J. Fish Biol. 2016, 88, 2236-2250. [CrossRef] 
27. Esteve, M. Observations of spawning behaviour in Salmoninae: Salmo, Oncorhynchus and Salvelinus. Rev. Fish Biol. Fish. 2005, 15, 1-21. [CrossRef]

28. Chapman, D.W.; Weitkamp, D.E.; Welsh, T.L.; Dell, M.B.; Schadt, T.H. Effects of river flow on the distribution of Chinook salmon redds. Trans. Am. Fish. Soc. 1986, 115, 537-547. [CrossRef]

29. IRKA. Alpenrhein: Quantitative Analyse von Schwall/Sunk-Ganglinien für unterschiedliche Anforderungsprofile; IRKA: Vaduz, Liechtenstein, 2012.

30. Moir, H.J.; Gibbins, C.N.; Soulsby, C.; Webb, J. Linking channel geomorphic characteristics to spatial patterns of spawning activity and discharge use by Atlantic salmon (Salmo salar L.). Geomorphology 2004, 60, 21-35. [CrossRef]

31. Becker, C.D.; Neitzel, D.A. Assessment of intergravel conditions influencing egg and alevin survival during salmonid redd dewatering. Environ. Biol. Fishes 1985, 12, 33-46. [CrossRef]

32. McMichael, G.A.; Rakowski, C.L.; James, B.B.; Lukas, J.A. Estimated Fall Chinook Salmon Survival to Emergence in Dewatered Redds in a Shallow Side Channel of the Columbia River. N. Am. J. Fish. Manag. 2005, 25, 876-884. [CrossRef]

33. Alfredsen, K.; Harby, A.; Linnansaari, T.; Ugedal, O. Development of an inflow-controlled environmental flow regime for a Norwegian river. River Res. Appl. 2012, 28, 731-739. [CrossRef]

34. Hauer, C.; Holzapfel, P.; Tonolla, D.; Habersack, H.; Zolezzi, G. In situ measurements of fine sediment infiltration (FSI) in gravel-bed rivers with a hydropeaking flow regime. Earth Surf. Process. Landf. 2018. [CrossRef]

35. Eberstaller, J.; Pinka, P. Trübung und Schwall Alpenrhein. Einfluss auf Substrat, Benthos, Fische. Teilbericht Fischökologie; BOKU: Wien, Austria, 2001.

36. Meile, T.; Fette, M.; Baumann, P. Synthesebericht Schwall/Sunk; Rhone-Thur Project, Swiss Federal Institute of Aquatic Science and Technology (EAWAG): Dübendorf, Switzerland, 2005.

37. Casas-Mulet, R.; Alfredsen, K.; Hamududu, B.; Timalsina, N.P. The effects of hydropeaking on hyporheic interactions based on field experiments. Hydrol. Process. 2015, 29, 1370-1384. [CrossRef]

38. Sternecker, K.; Geist, J. The effects of stream substratum composition on the emergence of salmonid fry. Ecol. Freshw. Fish 2010, 19, 537-544. [CrossRef]

39. O'Connor, W.C.K.; Andrew, T.E. The effects of siltation on Atlantic salmon, Salmo salar L., embryos in the River Bush. Fish. Manag. Ecol. 1998, 5, 393-401. [CrossRef]

40. Schälchli, U.; Abegg, J.; Hunzinger, L. Kolmation: Methoden zur Erkennung und Bewertung; Swiss Federal Institute of Aquatic Science and Technology (EAWAG): Dübendorf, Switzerland, 2002.

41. Buxton, T.H.; Buffington, J.M.; Yager, E.M.; Hassan, M.A.; Fremier, A.K. The relative stability of salmon redds and unspawned streambeds. Water Resour. Res. 2015, 51, 6074-6092. [CrossRef]

42. Unfer, G.; Hauer, C.; Lautsch, E. The influence of hydrology on the recruitment of brown trout in an Alpine river, the Ybbs River, Austria. Ecol. Freshw. Fish 2011, 20, 438-448. [CrossRef]

43. Casas-Mulet, R.; Saltveit, S.J.; Alfredsen, K. The Survival of Atlantic Salmon (Salmo salar) Eggs During Dewatering in a River Subjected to Hydropeaking. River Res. Appl. 2015, 31, 433-446. [CrossRef]

44. Becker, C.D.; Neitzel, D.A.; Fickeisen, D.H. Effects of dewatering on Chinook salmon redds: Tolerance of four developmental phases to daily dewaterings. Trans. Am. Fish. Soc. 1982, 111, 624-637. [CrossRef]

45. Becker, C.D.; Neitzel, D.A.; Abernethy, C.S. Effects of Dewatering on Chinook Salmon Redds: Tolerance of Four Development Phases to One-Time Dewatering. N. Am. J. Fish. Manag. 1983, 3, 373-382. [CrossRef]

46. Becker, C.D.; Neitzel, D.A.; Carlile, D.W. Survival data for dewatered Rainbow Trout (Salmo gairdneri Rich.) eggs and alevins. J. Appl. Ichthyol. 1986, 3, 102-110. [CrossRef]

47. Saltveit, S.J.; Brabrand, Å. Incubation, hatching and survival of eggs of Atlantic salmon (Salmo salar) in spawning redds influenced by groundwater. Limnologica 2013, 43, 325-331. [CrossRef]

48. Connor, E.J.; Pflug, D.E. Changes in the Distribution and Density of Pink, Chum, and Chinook Salmon Spawning in the Upper Skagit River in Response to Flow Management Measures. N. Am. J. Fish. Manag. 2004, 24, 835-852. [CrossRef]

49. Harnish, R.A.; Sharma, R.; McMichael, G.A.; Langshaw, R.B.; Pearsons, T.N. Effect of hydroelectric dam operations on the freshwater productivity of a Columbia River fall Chinook salmon population. Can. J. Fish. Aquat. Sci. 2014, 71, 602-615. [CrossRef] 
50. Irvine, R.L.; Thorley, J.L.; Westcott, R.; Schmidt, D.; Derosa, D. Why do fish strand? An analysis of ten years of flow reduction monitoring data from the Columbia and Kootenay rivers, Canada. River Res. Appl. 2015, 31, 1242-1250. [CrossRef]

51. Young, P.S.; Cech, J.J.; Thompson, L.C. Hydropower-related pulsed-flow impacts on stream fishes: A brief review, conceptual model, knowledge gaps, and research needs. Rev. Fish Biol. Fish. 2011, 21, 713-731. [CrossRef]

52. Schmutz, S.; Fohler, N.; Friedrich, T.; Fuhrmann, M.; Graf, W.; Greimel, F.; Höller, N.; Jungwirth, M.; Leitner, P.; Moog, O.; et al. Schwallproblematik an Österreichs Fließgewässern-Ökologische Folgen und Sanierungsmöglichkeiten; Bundesministerium für Land- und Forstwirtschaft, Umwelt und Wasserwirtschaft: Vienna, Austria, 2013.

53. Korman, J.; Walters, C.; Martell, S.J.D.; Pine Ill, W.E.; Dutterer, A. Effects of flow fluctuations on habitat use and survival of age-0 rainbow trout (Oncorhynchus mykiss) in a large, regulated river. Can. J. Fish. Aquat. Sci. 2011, 68, 1097-1109. [CrossRef]

54. Jensen, A.J.; Johnsen, B.O. The functional relationship between peak spring floods and survival and growth of juvenile Atlantic Salmon (Salmo salar) and Brown Trout (Salmo trutta). Funct. Ecol. 1999, 13, 778-785. [CrossRef]

55. Hurel, G. Impacts du fonctionnement par éclusées d'une usine hydroélectrique sur une population de truites communes (Salmo trutta L.) dans les Pyrénées ariégeoises (09); L’Ecole Nationale Supérieure Agronomique de Toulouse: Toulouse, France, 2010.

56. Auer, S.; Fohler, N.; Zeiringer, B.; Führer, S. Experimentelle Untersuchungen zur Schwallproblematik. Drift und Stranden von Äschen und Bachforellen während der ersten Lebensstadien; Institute of Hydrobiology and Aquatic Ecosystem Management, University of Natural Resources and Life Sciences, Vienna: Vienna, Austria, 2014.

57. Bauersfeld, K. Stranding of juvenile salmon by flow reductions at Mayfield Dam on the Cowlitz River, 1976; Washington Department of Fisheries: Tacoma, WA, USA, 1978.

58. Unfer, G.; Leitner, P.; Graf, W.; Auer, S. Der Einfluss von Schwallbetrieb auf den Fischbestand der Oberen Drau; VERBUND-Austrian Hydro Power AG and Bundesministerium für Land- und Forstwirtschaft, Umwelt und Wasserwirtschaft: Vienna, Austria, 2011.

59. Halleraker, J.H.; Sundt, H.; Alfredsen, K.T.; Dangelmaier, G. Application of multiscale environmental flow methodologies as tools for optimized management of a Norwegian regulated national salmon watercourse. River Res. Appl. 2007, 23, 493-510. [CrossRef]

60. Halleraker, J.H.; Saltveit, S.J.; Harby, A.; Arnekleiv, J.V.; Fjeldstad, H.-P.; Kohler, B. Factors influencing stranding of wild juvenile brown trout (Salmo trutta) during rapid and frequent flow decreases in an artificial stream. River Res. Appl. 2003, 19, 589-603. [CrossRef]

61. Liebig, H.; Cereghino, R.; Lim, P.; Belaud, A.; Lek, S. Impact of hydropeaking on the abundance of juvenile brown trout in a Pyrenean stream. Arch. für Hydrobiol. 1999, 4, 439-454. [CrossRef]

62. Jungwirth, M.; Winkler, H. The temperature dependence of embryonic development of grayling (Thymallus thymallus), Danube salmon (Hucho hucho), Arctic char (Salvelinus alpinus) and brown trout (Salmo trutta fario). Aquaculture 1984, 38, 315-327. [CrossRef]

63. Bradford, M.J. An experimental study of stranding of juvenile salmonids on gravel bars and in sidechannels during rapid flow decreases. Regul. Rivers Res. Manag. 1997, 13, 395-401. [CrossRef]

64. Bradford, M.J.; Taylor, G.C.; Allan, J.A.; Higgins, P.S. An experimental study of the stranding of juvenile coho salmon and rainbow trout during rapid flow decreases under winter conditions. N. Am. J. Fish. Manag. 1995, 15, 473-479. [CrossRef]

65. Heggenes, J.; Saltveit, S.J. Summer stream habitat partitioning by sympatric Arctic charr, Atlantic salmon and brown trout in two sub-arctic rivers. J. Fish Biol. 2007, 71, 1069-1081. [CrossRef]

66. Heggenes, J.; Krog, O.M.W.; Lindås, O.R.; Dokk, J.G.; Bremnes, T. Homeostatic behavioural responses in a changing environment: Brown trout (Salmo trutta) become nocturnal during winter. J. Anim. Ecol. 1993, 62, 295-308. [CrossRef]

67. Robertson, M.J.; Pennell, C.J.; Scruton, D.A.; Robertson, G.J.; Brown, J.A. Effect of increased flow on the behaviour of Atlantic salmon parr in winter. J. Fish Biol. 2004, 65, 1070-1079. [CrossRef]

68. Stickler, M.; Alfredsen, K.; Scruton, D.A.; Pennell, C.; Harby, A.; Økland, F. Mid-winter activity and movement of Atlantic salmon parr during ice formation events in a Norwegian regulated river. Hydrobiologia 2007, 582, 81-89. [CrossRef] 
69. Berland, G.; Nickelsen, T.; Heggenes, J.; Okland, F.; Thorstad, E.B.; Halleraker, J. Movements of wild Atlantic salmon parr in relation to peaking flows below a hydropower station. River Res. Appl. 2004, 20, 957-966. [CrossRef]

70. Puffer, M.; Berg, O.K.; Huusko, A.; Vehanen, T.; Forseth, T.; Einum, S. Seasonal Effects of Hydropeaking on Growth, Energetics and Movement of Juvenile Atlantic Salmon (Salmo salar). River Res. Appl. 2015, 31, 1101-1108. [CrossRef]

71. Boavida, I.; Harby, A.; Clarke, K.D.; Heggenes, J. Move or stay: Habitat use and movements by Atlantic salmon parr (Salmo salar) during induced rapid flow variations. Hydrobiologia 2017, 785, 261-275. [CrossRef]

72. Holzapfel, P.; Leitner, P.; Habersack, H.; Graf, W.; Hauer, C. Evaluation of hydropeaking impacts on the food web in alpine streams based on modelling of fish- and macroinvertebrate habitats. Sci. Total Environ. 2017, 575, 1489-1502. [CrossRef] [PubMed]

73. Sauterleute, J.F.; Hedger, R.D.; Hauer, C.; Pulg, U.; Skoglund, H.; Sundt-Hansen, L.E.; Bakken, T.H.; Ugedal, O. Modelling the effects of stranding on the Atlantic salmon population in the Dale River, Norway. Sci. Total Environ. 2016, 573, 574-584. [CrossRef] [PubMed]

74. Scruton, D.A.; Pennell, C.J.; Robertson, M.J.; Ollerhead, L.M.N.; Clarke, K.D.; Alfredsen, K.; Harby, A.; McKinsley, R.S. Seasonal Response of Juvenile Atlantic Salmon to Experimental Hydropeaking Power Generation in Newfoundland, Canada. N. Am. J. Fish. Manag. 2005, 25, 964-974. [CrossRef]

75. Scruton, D.A.; Pennell, C.; Ollerhead, L.M.N.; Alfredsen, K.; Stickler, M.; Harby, A.; Robertson, M.; Clarke, K.D.; LeDrew, L.J. A synopsis of "hydropeaking" studies on the response of juvenile Atlantic salmon to experimental flow alteration. Hydrobiologia 2008, 609, 263-275. [CrossRef]

76. Casas-Mulet, R.; Alfredsen, K.; Killingtveit, A. Modelling of environmental flow options for optimal Atlantic salmon, Salmo salar, embryo survival during hydropeaking. Fish. Manag. Ecol. 2014, 21, 480-490. [CrossRef]

77. Yarnell, S.M.; Petts, G.E.; Schmidt, J.C.; Whipple, A.A.; Beller, E.E.; Dahm, C.N.; Goodwin, P.; Viers, J.H. Functional Flows in Modified Riverscapes: Hydrographs, Habitats and Opportunities. Bioscience 2015, 65, 963-972. [CrossRef]

78. Naiman, R.J.; Latterell, J.J.; Pettit, N.E.; Olden, J.D. Flow variability and the biophysical vitality of river systems. C. R. Geosci. 2008, 340, 629-643. [CrossRef]

79. Greimel, F.; Zeiringer, B.; Höller, N.; Grün, B.; Godina, R.; Schmutz, S. A method to detect and characterize sub-daily flow fluctuations. Hydrol. Process. 2016, 30, 2063-2078. [CrossRef]

80. Hauer, C.; Unfer, G.; Holzapfel, P.; Haimann, M.; Habersack, H. Impact of channel bar form and grain size variability on estimated stranding risk of juvenile brown trout during hydropeaking. Earth Surf. Process. Landf. 2014, 39, 1622-1641. [CrossRef]

81. Tuhtan, J.A.; Noack, M.; Wieprecht, S. Estimating stranding risk due to hydropeaking for juvenile European grayling considering river morphology. KSCE J. Civ. Eng. 2012, 16, 197-206. [CrossRef]

82. Hauer, C.; Unfer, G.; Graf, W.; Holzapfel, P.; Leitner, P.; Habersack, H. Grundlagenuntersuchungen und Methodikentwicklung zur Bewertung des Wasserkraft-Schwalls bei unterschiedlichen Flusstypen. Österreichische Wasser- und Abfallwirtschaft 2013, 65, 324-338. [CrossRef]

83. Harby, A.; Noack, M. Rapid Flow Fluctuations and Impacts on Fish and the Aquatic Ecosystem. In Ecohydraulics: An Integrated Approach; Maddock, I., Harby, A., Kemp, P., Wood, P., Eds.; John Wiley \& Sons, Ltd.: Hoboken, NJ, USA, 2013; pp. 323-335.

84. Zolezzi, G.; Siviglia, A.; Toffolon, M.; Maiolini, B. Thermopeaking in alpine streams: Event characterization and time scales. Ecohydrology 2011, 4, 564-576. [CrossRef]

85. Olden, J.D.; Naiman, R.J. Incorporating thermal regimes into environmental flows assessments: Modifying dam operations to restore freshwater ecosystem integrity. Freshw. Biol. 2010, 55, 86-107. [CrossRef]

86. Schülting, L.; Feld, C.K.; Graf, W. Effects of hydro- and thermopeaking on benthic macroinvertebrate drift. Sci. Total Environ. 2016, 573, 1472-1480. [CrossRef] [PubMed]

87. Wallace, J.B.; Webster, J.R. The role of macroinvertebrates in stream ecosystem function. Annu. Rev. Entomol. 1996, 41, 115-139. [CrossRef] [PubMed]

88. Pulg, U.; Vollset, K.W.; Velle, G.; Stranzl, S. First observations of saturopeaking: Characteristics and implications. Sci. Total Environ. 2016, 573, 1615-1621. [CrossRef] [PubMed]

89. Lumsdon, A.E.; Artamonov, I.; Bruno, M.C.; Righetti, M.; Tockner, K.; Tonolla, D.; Zarfl, C. SoundpeakingHydropeaking induced changes in river soundscapes. River Res. Appl. 2018, 34, 3-12. [CrossRef] 
90. Tonolla, D.; Bruder, A.; Schweizer, S. Evaluation of mitigation measures to reduce hydropeaking impacts on river ecosystems-A case study from the Swiss Alps. Sci. Total Environ. 2017, 574, 594-604. [CrossRef] [PubMed]

91. Pragana, I.; Boavida, I.; Cortes, R.; Pinheiro, A. Hydropower Plant Operation Scenarios to Improve Brown Trout Habitat. River Res. Appl. 2017, 33, 364-376. [CrossRef]

92. L'Abée-Lund, J.H.; Otero, J. Hydropeaking in small hydropower in Norway-Compliance with license conditions? River Res. Appl. 2018, 34, 372-381. [CrossRef]

93. Costa, M.J.; Boavida, I.; Almeida, V.; Cooke, S.J.; Pinheiro, A.N. Do artificial velocity refuges mitigate the physiological and behavioural consequences of hydropeaking on a freshwater Iberian cyprinid? Ecohydrology 2018, 11, e1983. [CrossRef]

94. Storli, P.-T. Novel methods of increasing the storage volume at Pumped Storage Power plants. Int. J. Fluid Mach. Syst. 2017, 10, 209-2017. [CrossRef]

95. HydroFlex. Social Acceptance and Mitigation of Environmental Impact. Available online: https:// h2020hydroflex.eu/work-packages/wp-5/ (accessed on 6 March 2019).

96. Northcote, T.G.; Lobón-Cerviá, J. Increasing experimental approaches in stream trout research-1987-2006. Ecol. Freshw. Fish 2008, 17, 349-361. [CrossRef]

97. Northcote, T.G. Comparative biology and management of Arctic and European grayling (Salmonidae, Thymallus). Rev. Fish Biol. Fish. 1995, 5, 141-194. [CrossRef]

98. Jonsson, B.; Jonsson, N. A review of the likely effects of climate change on anadromous Atlantic salmon Salmo salar and brown trout Salmo trutta, with particular reference to water temperature and flow. J. Fish Biol. 2009, 75, 2381-2447. [CrossRef] [PubMed]

99. Bejarano, M.D.; Jansson, R.; Nilsson, C. The effects of hydropeaking on riverine plants: A review. Biol. Rev. 2018, 93, 658-673. [CrossRef]

100. Lucas, M.C.; Baras, E. Migration of Freshwater Fishes; Blackwell Science Ltd.: Hoboken, NJ, USA, 2001.

101. Crisp, D.T. Environmental requirements of common riverine European salmonid fish species in fresh water with particular reference to physical and chemical aspects. Hydrobiologia 1996, 323, 201-221. [CrossRef]

102. Lobón-Cerviá, J.; Sanz, N. (Eds.) Brown Trout: Biology, Ecology and Management; John Wiley \& Sons, Ltd.: Hoboken, NJ, USA, 2018.

103. Fabricius, E.; Gustafson, K.-J. Observations on the spawning behaviour of the grayling, Thymallus thymallus (L.). Rep. Inst. Freshw. Res. Drottningholm 1955, 36, 75-103.

104. Gibson, R.J. The Atlantic salmon in fresh water: Spawning, rearing and production. Rev. Fish Biol. Fish. 1993, 3, 39-73. [CrossRef]

105. Jonsson, B.; Jonsson, N. Ecology of Atlantic Salmon and Brown Trout; Springer Science \& Business Media: Berlin, Germany, 2011.

106. Flodmark, L.E.W.; Vøllestad, L.A.; Forseth, T. Performance of juvenile brown trout exposed to fluctuating water level and temperature. J. Fish Biol. 2004, 65, 460-470. [CrossRef]

107. Vehanen, T.; Huusko, A.; Yrjänä, T.; Lahti, M.; Mäki-Petäys, A. Habitat preference by grayling (Thymallus thymallus) in an artificially modified, hydropeaking riverbed: A contribution to understand the effectiveness of habitat enhancement measures. J. Appl. Ichthyol. 2003, 19, 15-20. [CrossRef]

(C) 2019 by the authors. Licensee MDPI, Basel, Switzerland. This article is an open access article distributed under the terms and conditions of the Creative Commons Attribution (CC BY) license (http://creativecommons.org/licenses/by/4.0/). 